\title{
A Comparison of Three Strains of Holstein-Friesian Cows Grazed on Pasture: Growth, Development, and Puberty
}

\author{
K. A. Macdonald, ${ }^{* 1}$ L. R. McNaughton, $\dagger$ G. A. Verkerk, ${ }^{*}$ J. W. Penno, ${ }^{* 2}$ L. J. Burton, $\dagger$ D. P. Berry, $\ddagger$ \\ P. J. S. Gore, ${ }^{\star}$ J. A. S. Lancaster, ${ }^{\star}$ and C. W. Holmes§ \\ ${ }^{*}$ Dexcel, Private Bag 3221, Hamilton, New Zealand \\ tLIC, Private Bag 3123, Hamilton, New Zealand \\ ‡Dairy Production Department, Teagasc, Moorepark Production Research Centre, Fermoy, Co. Cork, Ireland \\ §Institute of Veterinary, Animal and Biomedical Sciences, Massey University, Private Bag 11222, Palmerston North, New Zealand
}

\section{ABSTRACT}

With the introduction of a protein milk payment system in New Zealand in 1988, there was an influx of North American (NA) Holstein-Friesian (HF) genetics into New Zealand (NZ) dairy herds, leading to an increase in the average percentage of NA genetics in NZ $\mathrm{HF}$ cows-from $2 \%$ in 1980 to $38 \%$ in 1999 . Of interest has been the effect this change has had on farm profitability and on the management required for these animals, as well as the phenotypic changes that have occurred within the national herd under the breeding programs operated in NZ from 1970 to 1990 . The objective of this study was to quantify differences in body dimensions, body weights, and puberty-related parameters among 3 strains of $\mathrm{HF}$, representing animals of $\mathrm{NZ}$ origin representative of the genetics present in 1970 and 1990 and of NA origin with 1990s genetics. A total of 172 animals born in 1999 were compared. The strains were 1) NZ70, a strain of NZ Friesian (average 7\% NA genetics) equivalent to high-genetic-merit (high Breeding Worth) cows farmed in the 1970s; 2) NZ90, a strain of $\mathrm{HF}$ of $\mathrm{NZ}$ origin (average $24 \% \mathrm{NA}$ genetics) typical of the animals present in the 1990s; and 3) NA90, a strain of $\mathrm{HF}$ of NA origin (average of $91 \%$ NA genetics) typical of animals present in the 1990s. The differences in BW among all strains were significant at 6 and 12 mo of age. At 15 and $24 \mathrm{mo}$, the $2 \mathrm{NZ}$ strains were significantly lighter than the NA90 animals. At 24 mo of age (i.e., prior to first calving), the NA90 strain animals $(\mathrm{BW}=515 \mathrm{~kg})$ were 22 and $34 \mathrm{~kg}$ heavier than the NZ90 and NZ70 strains. The body length of the NA90 strain was greater than either of the $2 \mathrm{NZ}$ strains; the differences among the NA90 strain and the 2 NZ strains

Received February 15, 2007.

Accepted April 17, 2007.

${ }^{1}$ Corresponding author: Kevin.macdonald@dexcel.co.nz

${ }^{2}$ Current address: Synlait, RD 13, Te Pirita Rd, Rakaia, New Zealand. varied from 2 to $6 \mathrm{~cm}$, with the differences generally being greater at older ages. The trend in heart girth difference among strains was similar to that observed for body length. The wither height of the NA90 animals was greater than that of the NZ strains by 1 to $7 \mathrm{~cm}$, although there was no significant difference between the NA90 and NZ90 strains at birth. At puberty the NA90 heifers were $20 \mathrm{~d}$ older and $20 \mathrm{~kg}$ heavier than the NZ90 heifers, which in turn were $25 \mathrm{~kg}$ and $25 \mathrm{~d}$ older than the NZ70 heifers. The NA90 strain had a heavier mature body weight, and their older age at puberty suggested either that they mature later or that, under pastoral conditions, their growth rate is limited by their inability to consume sufficient metabolizable energy as grazed pasture, with a consequent delay in puberty. Results from this study will be useful in revising target $\mathrm{BW}$ in growing heifers of different germplasm.

Key words: strain, Holstein-Friesian, body weight, body size

\section{INTRODUCTION}

To achieve optimal profitability in dairy production, the type of cow farmed must be suitable for the production system operated. Dairying systems differ markedly among North America (NA), Europe, and New Zealand (NZ), and as a consequence, dairy selection objectives also differ. The use of NA Holstein-Friesian (HF) semen in NZ in the last $20 \mathrm{yr}$ has significantly changed the genetic composition of the NZ national herd (Harris and Kolver, 2001).

This change in genotype is likely to have economic consequences for NZ farming and for other countries with pasture-based dairying systems, because NZ and NA HF are known to differ phenotypically. Based on US information for pasture-based dairies, milk production for NA HF exceeds that of NZ genetics. When NZ and NA HF were compared in NZ and Ireland, although there was no difference when cows were fed predomi- 
nantly pasture, there was greater production from NA cows when concentrate was fed (Kolver et al., 2000; Harris and Kolver, 2001; Horan et al., 2004). The reported inconsistencies could therefore be a result of differences in the amount of concentrate supplements being fed in these systems, or they may be a result of failing to account for differences in energy partitioning to BCS. North American cows mobilize more BCS in early lactation, have a longer postpartum period of negative energy balance, and partition less energy to BCS postnadir (Roche et al., 2006). This condition must be replenished through additional feeding in late lactation or during the nonlactating period, and failure to account for this overestimates the efficiency of NA HF relative to NZ HF.

Despite early indications of a genotype and environment interaction (Holmes, 1995), heavy use was made of NA HF in NZ, because the genetic merit index ranked the NA HF highly. When milk protein became part of the NZ milk payment system, with a reduced emphasis on milk fat, there was an influx of NA HF genetics. From 1980 to 1999 , the average percentage of NA genetics in HF calves born increased from 2 to $38 \%$ (Harris and Kolver, 2001).

Prior to the 1960s in NZ, milk fat was the main source of income, and production values given to dairy cattle were relative to their milk fat production. In the $1980 \mathrm{~s}$ protein was included in the breeding indices and milk volume was penalized. In 1996 the Breeding Worth index was introduced and was the main measurement of genetic merit, comprising EBV and an economic value for EBV. The Breeding Worth index includes 1) payment for milk fat plus milk protein minus a cost for milk volume; 2) returns from culls and calves via BW information; and 3) total feed requirements, which are calculated from production information and BW. Breeding Worth is expressed as net lifetime income per 4.5 tonne of feed DM required.

One consequence of the increase in NA HF genetics is likely to be an increase in heifer size and weight at puberty, requiring faster growth rates to reach puberty at the same age as animals of NZ genetic origin (GarcíaMuñiz, 1998; Harris and Kolver, 2001). Heifer growth rate and BW at first calving are regarded as important benchmarks in dairy farm management (Sejrsen and Purup, 1997). Spelman and Garrick (1997) illustrated how cow BW affects farm profitability on a pasturebased system of milk production through both cow maintenance requirements and marginal BW returns from culled cows and calves sold for slaughter.

In the NZ system of dairy production, heifers normally calve at $24 \mathrm{mo}$, having conceived at around 15 mo of age. Heifers born late in the calving period may be younger when conceiving and calving than their counterparts born earlier. Early onset of puberty is therefore advantageous to ensure that all heifers are pubertal and cycling regularly before the start of mating, which begins at a fixed calendar date, regardless of the age of the heifer. Level of nutrition, BW, age, degree of body fat, and photoperiod have been identified as some of the traits that influence the onset of puberty (Foster, 1994).

The project reported here (Dexcel Strain Trial) was a collaborative experiment among Dexcel, Massey University, LIC, and Moorepark Research Institute (Ireland). A similar set of animals were reared in Ireland (Berry et al., 2005). The objectives of this research were to 1) establish whether NA HF dairy cows can be profitably used in NZ pasture-based feeding systems; 2) establish the importance of genotype by environment interactions among the effects of 3 genotypes and differing levels of feed inputs on milk production, efficiency, health, and fertility; and 3) determine the level of genetic progress that has been made in milk production, feed conversion efficiency, fertility, and other characteristics of on-farm profitability in NZ since 1970. This paper is part of a series on the Dexcel Strain Trial (milk production, intake, BCS, BW, reproduction, and economics of the strains under differing pasture feed allowances) and concentrates on growth, development, and puberty of 3 strains of $\mathrm{HF}$.

\section{MATERIALS AND METHODS}

This experiment was undertaken at Dexcel, Hamilton, New Zealand (latitude $37^{\circ} 47^{\prime} \mathrm{S}$, longitude $175^{\circ} 19^{\prime}$ $\mathrm{E}, 40 \mathrm{~m}$ above sea level). Beginning in July 1999, 3 strains of HF were reared and their physical measurements were recorded from arrival at Dexcel until May 2004. Only animals born in 1999 are reported here.

\section{Animals}

The animals used in the present study were sourced from Dexcel farms (11\%) and commercial dairy farms from within NZ. The dams of selected calves were milk recorded and had at least 3 generations of pedigree. Dominance of any sire lines in the dam pedigrees was avoided. The 3 strains developed were the NZ70, NZ90, and NA90 strains.

NZ70 Strain. The NZ70 strain is a strain of NZ Friesian equivalent to high Breeding Worth in the 1970s. This strain of cow is representative of the selection and breeding policies in NZ before the 1970s. These animals were generated using semen stored from that era by LIC. Dams were representative of cows in the NZ population in the 1970s selected for high milk fat yield. Estimated breeding values (November 1999) and 
Table 1. Estimated breeding values $( \pm \mathrm{SD})$ calculated in November 1999 for the 3 strains of Holstein-Friesian cows in the strain trial

\begin{tabular}{lccc}
\hline & \multicolumn{3}{c}{ Treatment $^{1}$} \\
\cline { 2 - 4 } Item & NZ70 & NZ90 & NA90 \\
\hline Fat, kg & $12 \pm 8.8$ & $40 \pm 5.5$ & $36 \pm 5.0$ \\
Protein, kg & $9 \pm 8.2$ & $38 \pm 4.6$ & $44 \pm 3.7$ \\
Milk, kg & $495 \pm 223.2$ & $1,072 \pm 162.4$ & $1,362 \pm 139.5$ \\
BW, kg & $47 \pm 14.8$ & $49 \pm 8.7$ & $83 \pm 7.2$ \\
Breeding Worth, $\$$ & $-10 \pm 21.9$ & $86 \pm 11.9$ & $84 \pm 9.3$ \\
\hline
\end{tabular}

${ }^{1}$ Treatments: NZ70 = a 1970s high Breeding Worth strain of New Zealand Friesian; NZ90 = a 1990s high Breeding Worth HolsteinFriesian of New Zealand origin; NA90 = a 1990s high Breeding Worth Holstein-Friesian of North American origin.

Breeding Worth for the animals used are shown in Table 1 . These animals had 7\% NA HF genetics.

NZ90 Strain. The NZ90 strain is a strain of HF of NZ origin with a high Breeding Worth in the 1990s. This strain was generated from sires and dams with a low proportion of NA genes and is representative of NZ selection and breeding policies present in the 1990s. These animals had 24\% NA HF genetics.

NA90 Strain. The NA90 strain is a strain of $\mathrm{HF}$ of NA origin, with a high Breeding Worth in the 1990s. This strain was established by breeding NZ-born cows that had a high proportion of NA genetics in their ancestry to sires of principally NA origin. These sires were in common use within NZ at that time because of their high protein and milk EBV. These animals had $91 \%$ NA HF genetics.

\section{Heifer Rearing}

Colostrum was fed immediately after birth (minimum $2 \mathrm{~L}$ within the first $12 \mathrm{~h}$ of life), and colostrum and transitional milk were fed for the next $4 \mathrm{~d}$. At the time calves were collected from their farm of birth, the dam (and the birth mother in the case of embryo-transfer calves) and the calf were blood sampled by coccygeal venipuncture for DNA parentage verification. Body weights of calves born on the North Island were measured immediately on arrival at Dexcel and then fortnightly with load-cell scales (Tru-Test NZ Ltd., Auckland, New Zealand) after incorporation into rearing groups of similar age and size. Calves were housed in groups of 20 to 40 in well-ventilated but draft-free housing until they were strong enough to be managed outdoors, with due regard to prevailing weather conditions. A small number of calves were born on the South Island, where an initial blood sample was obtained by the vendor's veterinarian, and the samples were forwarded to Dexcel for DNA parentage verification. These calves were reared under contract on the vendors' properties and were transported to the Dexcel Research Farm at approximately $120 \mathrm{~d}$ of age.

Calves were fed whole milk through a calf feeder equipped with rubber teats. Concentrates [minimum $18 \%$, maximum $24 \% \mathrm{CP}$ and minimum $7.2 \mathrm{MJ}$ of net energy (1.72 Mcal of net energy)/kg of DM] and barley straw were offered from d 7 onward. Weaning occurred between 8 and 10 wh of age when the calves had adjusted to grazing pasture and eating concentrate while maintaining satisfactory growth rates (minimum weights of 71 and $79 \mathrm{~kg}$ for the NZ and NA strain, respectively). Following weaning, calves were managed in groups of approximately 35 animals of similar age within strain and fed good-quality pasture, pasture silage, and meal (for at least 4 wk to ensure weaning transition) in adequate quantities to maintain the required growth rates, with 5\% extra feed as a margin to ensure that their "ability to grow" was not limited by pasture intake.

Differing BW targets were set for the NA90 and the NZ strains. Recommendations in the literature suggested that BW after first calving in NA HF heifers should be 540 to $600 \mathrm{~kg}$ (Heinrichs, 1993). The target BW of the NZ strains were set from their expected mature BW, calculated from the BW EBV. Expected BW were as follows: birth $=35$ and $40 \mathrm{~kg}$, and targets for weaning $=85$ and $90 \mathrm{~kg}, 6 \mathrm{mo}=160$ and $170 \mathrm{~kg}$, $15 \mathrm{mo}$ (mating) $=310$ and $335 \mathrm{~kg}, 24 \mathrm{mo}=470$ and 500 $\mathrm{kg}$, and mature $\mathrm{BW}=519$ and $555 \mathrm{~kg}$ for the $2 \mathrm{NZ}$ strains and the NA90 animals, respectively.

Pasture offered was predominantly perennial ryegrass (Lolium perenne L.) and white clover (Trifolium repens L.), with less than $20 \%$ weeds and other grasses (Dactylis glomerata L.; Poa annua L.). Each strain group was grazed separately in 0.4-ha paddocks, and a different pasture area was allocated to adjust stocking density (animals/ha per d) and thereby achieve a target BW for each strain.

\section{Heifer Health}

During early rearing, the calves were fed concentrate, which contained a proprietary coccidiostat. Fecal egg counts for strongyloid worms were monitored before the postweaning drench and then at every second weighing period from a selected group of calves (15 per strain). The requirement for anthelmintic treatment was determined on the basis of the fecal egg counts. In general, treatments with an avomectin-based product were at intervals of approximately 6 to $8 \mathrm{wk}$ until autumn, then at intervals of approximately 3 mo. Regular inspection of the animals was used to identify the presence of lice, ticks, or both, and if detected, the animals were treated with an appropriate endectocide. 
An immunization program was carried out against economically important infectious diseases, namely, clostridial diseases (tetanus and blackleg), leptospirosis (pomona, hardjo, and copenhageni), and bovine viral diarrhea virus. Additionally, zinc sulfate $(8 \mathrm{~g}$ of $\mathrm{ZnSO}_{4} \cdot 7 \mathrm{H}_{2} \mathrm{O} / \mathrm{kg}$ of BW) was added to the drinking water via a Peta dispenser (Peta Enterprises, Hamilton, New Zealand) during periods of increased vulnerability to facial eczema, as determined by pasture fungal (Pithomyces chartarum) spore counts.

\section{Puberty}

To determine the date of puberty, blood samples were collected weekly from each heifer that had reached 195 $\mathrm{kg}$ (both NZ strains) or $215 \mathrm{~kg}$ (NA90 strain) of BW. All prepubertal heifers were sampled for the last $4 \mathrm{wk}$ of the sampling period, regardless of their BW. Sampling ceased $14 \mathrm{~d}$ before the start of mating to allow induction of estrus in heifers that were prepubertal. Progesterone plasma concentrations were measured by RIA (Coat-aCount, Diagnostic Products Corporation, Los Angeles, CA). Interassay coefficients of variation for plasma pools of $4.43,3.04$, and $0.40 \mathrm{ng} / \mathrm{mL}$ were $7.3,5.4$, and $12.4 \%$, respectively. Intraassay coefficients of variation for the same plasma pools were $6.8,5.7$, and $13.6 \%$ over 52 assays. The minimum detectable concentration of the assay was $0.061 \mathrm{ng} / \mathrm{mL}$. Puberty was considered to have occurred when plasma progesterone concentrations of $2 \mathrm{ng} / \mathrm{mL}$ were present in 2 out of 3 consecutive samples. The date of puberty was recorded as the time the first of these samples was collected. Body weight at puberty was estimated by interpolation from 2 weekly weighings.

The plasma progesterone records were examined at the end of September, at which time any animals that had progesterone concentrations of $>1 \mathrm{ng} / \mathrm{mL}$ were considered to be either cycling or close to cycling, despite having failed to reach the criteria for puberty. The remaining animals $(n=13)$ were treated with an 8-d controlled internal drug release (CIDR) intravaginal insert (Interag, Hamilton, New Zealand), followed by $\mathrm{PGF}_{2 \alpha}(5 \mathrm{~mL}$ of Lutalyse, Pharmacia and Upjohn, Auckland, New Zealand) at the time of CIDR removal. Heifers that were in estrus $24 \mathrm{~h}$ after CIDR removal were inseminated. All other animals were injected with 0.75 mg of estradiol benzoate (Intervet Ltd., Auckland, New Zealand), and then fixed-time inseminated to Jersey bulls on the following day and returned to the main herd. Pubertal animals were naturally mated to yearling Jersey bulls, with the bulls introduced to the herds on October 10 and removed December 20, 2000.

\section{Management from 22 mo}

At 22 mo of age, the heifers were transferred to Dexcel No. 2 Dairy, a research dairy farm situated adjacent to the calf-rearing unit. The animals were managed under a set of decision rules aimed to optimize cow performance at stocking rates that are sufficiently generous to achieve high rates of pasture utilization (Macdonald and Penno, 1998), and to ensure that different research farmlets were treated consistently both within and between years. Application of these rules requires many of the variables within the dairy farming system to be quantified, thereby removing subjectivity from management decisions. The systems under which the strains were managed were designed to provide feed allowances of 4.5 to 7.0 tonne of DM/cow per yr, based on different stocking rates and supplement inputs. When feed allowances higher than 5.5 tonne of $\mathrm{DM} /$ cow were required, additional feed was brought in as either corn silage or corn grain to supplement the pasture grown. A full description of the trial design is provided in Macdonald et al. (2005a).

\section{Data Measurements and Analyses}

$\boldsymbol{B W}$. A total of 172 animals were used in the farm study (36 were NZ70, 68 were NZ90, and 68 were NA90). Upon arrival at the Dexcel calf-rearing facility, all the calves were weighed and thereafter were weighed every other week. Five time points of particular interest in the life of the animals before first calving were identified: birth, $6 \mathrm{mo}, 12 \mathrm{mo}, 15 \mathrm{mo}$, and first calving. Birth BW was defined as the first BW measure of an animal but within the first week of life; data were available for a total of 126 animals. The lower number of records for birth weight was due to the delay in assembly of animals born on the South Island. Body weight at 6 and 12 mo of age was the nearest BW record to 180 and $360 \mathrm{~d}$, respectively, but within $7 \mathrm{~d}$ of the respective day of interest; $\mathrm{BW}$ at 15 mo was the nearest BW record to $450 \mathrm{~d}$ of age but between 438 and $462 \mathrm{~d}$. If an observation was available equidistant from the day of interest, then the earlier observation was retained. For BW at first calving, the observation immediately before first calving but within 2 wk of calving was used. A total of 164, 165, 143, and 171 records were available for inclusion in the analysis of BW at $6 \mathrm{mo}$, $12 \mathrm{mo}, 15 \mathrm{mo}$, and first calving, respectively.

Body condition score was assessed at $6,12,18$, and 24 mo on all animals on a 10-point scale, where 1 is emaciated and 10 is obese (Macdonald and Roche, 2004). These scores can be converted to the scales used in other countries with a regression equation (United States $=1.5+0.32 \mathrm{NZ}$; Ireland $=0.81+0.4 \mathrm{NZ}$; and Australia $=2.2+0.54 \mathrm{NZ}$ ). 
Two analyses were undertaken on BW. First, BW from birth to 15 mo of age was analyzed using the mixed models in PROC MIXED (SAS Institute, 2005). Explanatory variables included in the model were strain, stage of life, week of birth, and a 2-way interaction between strain and stage of life. All terms were significant $(P<0.05)$ in the model. Body weight was treated as the repeated trait across stages with a firstorder autoregressive correlation structure with heterogeneous variances assumed among records within animal. The error correlation matrix structure was chosen based on minimization of Akaike's information criterion as well as on identification of decreasing correlations and increasing variances with time using PROC CORR (SAS Institute, 2005). Sire was included as a random effect. Least squares means of strain by stage of life were extracted from the analysis and compared using $t$-tests.

Because age at first calving (the last time an animal was weighed relative to first calving) varied across animals, BW at first calving was not included in the mixed model analysis but was treated as a separate trait and analyzed using PROC MIXED (SAS Institute, 2005). Included in the model were strain, week of birth, and age of the animal when the BW was taken. Sire was included as a random effect in the model. Number of days from when the BW was measured to first calving was not significant in the model. An additional analysis was undertaken in which BCS at first calving was included as a continuous independent variable in the analysis of BW at calving, thereby accounting for differences in BCS at calving among animals.

\section{Body Dimensions}

Upon arrival at the Dexcel calf-rearing facility, all the calves were assessed for wither height (WH). In addition, body length (BL), heart girth (HG), and WH were recorded in centimeters at approximately 6,12 , 18, 24, and 36 mo. Body length was defined as the horizontal distance between the bottom of the pin bones and the top of the withers, HG was defined as the circumference of the animal girth measured directly behind the front legs, and WH was recorded as the vertical distance from the ground to the top of the withers. The data consisted of 931 records on as many as 4 body dimensions across 172 animals. The numbers of animal length, HG, and WH measurements in the data set were 804,805 , and 931 , respectively.

Age at assessment was divided into 5 classes corresponding to the approximate time of assessment; $\mathrm{WH}$ at birth was included as an additional class. The mean and standard deviation in age (d) within the 5 stages of life ( 6 stages for WH) were $4 \pm 1.4,162 \pm 16.1,374$ $\pm 15.1,532 \pm 15.9,706 \pm 15.9$, and $1,064 \pm 15.8 \mathrm{~d}$ for the stages of birth, $6 \mathrm{mo}, 12 \mathrm{mo}, 15 \mathrm{mo}, 24 \mathrm{mo}$, and 36 mo, respectively. Berry et al. (2005) reported no significant effect of feed system on body dimensions. A preliminary analysis of the present data set revealed no systematic effect of feed system across the strains, probably because the feeding systems were imposed on the animals from approximately $22 \mathrm{mo}$ of age. Hence, none of the body dimensions were adjusted for feed system.

The effect of strain was evaluated in PROC MIXED (SAS Institute, 2005) separately for each body trait. The model was adjusted for stage of life, age nested within life stage, strain, and a strain by life stage interaction. The body trait under investigation was treated as the repeated trait across stages, with a compound symmetry error correlation structure with heterogeneous variances assumed within animal. The error correlation matrix structure was chosen based on minimizing the AIC as well as the identification of relatively similar correlations between body dimensions at different life stages with PROC CORR (SAS Institute, 2005) but heterogeneous variances across stages. Sire was included as a random effect in the model. Least squares means of strain by stage of life were extracted from the analysis and compared with $t$-tests.

Puberty. A total of 190 animals were available for inclusion in the analysis, of which 41 were NZ70, 73 were NZ90, and 76 were NA90. Proportional data were analyzed using the chi-squared test (SAS Institute, 2005). Continuous data were analyzed using PROC MIXED (SAS Institute, 2005) with a model that included the fixed effect of strain and a random effect of sire. A further analysis was conducted in S-Plus 2000 (Insightful Corp., Seattle, WA) with frailty models (sire was nested within strain) to estimate age and BW at puberty for each strain in which all animals had the opportunity to reach puberty.

\section{RESULTS}

There was a strain $(P<0.001)$, stage $(P<0.001)$, and strain by stage interaction $(P<0.05)$ for all physical measurements. The least squares means for BW, BL, $\mathrm{HG}$, and WH for the 3 strains across the different age categories are shown in Tables 2 and 3. The average birth weight of the NZ70 calves $(37.5 \mathrm{~kg})$ was lower $(P$ $<0.001)$ than the birth weights of the NZ90 $(41.8 \mathrm{~kg})$ and NA90 $(41.9 \mathrm{~kg})$ calves. The NA90 animals were heavier $(P<0.001)$ than the $2 \mathrm{NZ}$ strains at all other stages of life. The NA90 strain weighed $515 \mathrm{~kg}$ at calving and were 24 and $34 \mathrm{~kg}$ heavier $(P<0.001)$ than the NZ90 and NZ70 strains, respectively (Table 2).

Differences in BCS between strains at first calving were significant $(P<0.05)$. Values were $5.4,5.6$, and 
Table 2. Mean BW $( \pm \mathrm{SE})$ of the animals by strain up to 24 mo of age

\begin{tabular}{lrrr}
\hline & \multicolumn{3}{c}{ Treatment $^{1}$} \\
\cline { 2 - 4 } BW, kg & \multicolumn{1}{c}{ NZ70 } & \multicolumn{1}{c}{ NZ90 } & \multicolumn{1}{c}{ NA90 } \\
\hline $4 \mathrm{~d}$ & $37.5^{\mathrm{a}} \pm 1.59$ & $41.9^{\mathrm{b}} \pm 1.38$ & $41.8^{\mathrm{b}} \pm 1.30$ \\
6 mo & $152.7^{\mathrm{a}} \pm 2.78$ & $162.4^{\mathrm{b}} \pm 2.21$ & $168.8^{\mathrm{c}} \pm 2.10$ \\
$12 \mathrm{mo}$ & $239.2^{\mathrm{a}} \pm 3.51$ & $248.8^{\mathrm{b}} \pm 2.69$ & $257.6^{\mathrm{c}} \pm 2.62$ \\
$15 \mathrm{mo}$ & $330.7^{\mathrm{a}} \pm 4.71$ & $337.2^{\mathrm{a}} \pm 3.45$ & $361.5^{\mathrm{b}} \pm 3.55$ \\
$24 \mathrm{mo}$ & $481.1^{\mathrm{a}} \pm 7.74$ & $490.9^{\mathrm{a}} \pm 6.92$ & $514.7^{\mathrm{b}} \pm 6.32$ \\
\hline
\end{tabular}

${ }^{\mathrm{a}-\mathrm{c}}$ Values within rows with different superscripts differ $(P<0.05)$.

${ }^{1}$ Treatments: NZ70 = a 1970s high Breeding Worth strain of New Zealand Friesian; NZ90 = a 1990s high Breeding Worth HolsteinFriesian of New Zealand origin; NA90 = a 1990s high Breeding Worth Holstein-Friesian of North American origin.

5.7 for the NA90, NZ90, and NZ70 strains, respectively. However, following adjustment of calving BW for differences in BCS at calving, BW of the NA90, NZ90, and NZ70 strains were 523,488 , and $471 \mathrm{~kg}$, respectively, with the NA90 animals being heavier $(P<0.001)$ than the NZ animals and with no significant difference between the NZ strains.

The NA90 strain was always longer $(P<0.05)$ than either of the $2 \mathrm{NZ}$ strains (Table 3 ). The difference between the NA90 strain and the $2 \mathrm{NZ}$ strains varied from 2 to $6 \mathrm{~cm}$, with the differences being greater at older ages. The NZ90 strain was consistently longer $(P$ $<0.001)$ than the NZ70 strain throughout the different

Table 3. Mean length, heart girth, and wither height $( \pm \mathrm{SE})$ of the animals by strain up to 36 mo of age

\begin{tabular}{|c|c|c|c|}
\hline \multirow[b]{2}{*}{ Item } & \multicolumn{3}{|c|}{ Treatment $^{1}$} \\
\hline & NZ70 & NZ90 & NA90 \\
\hline \multicolumn{4}{|c|}{ Length, $\mathrm{cm}$} \\
\hline $6 \mathrm{mo}$ & $88.0^{\mathrm{a}} \pm 0.91$ & $88.2^{\mathrm{a}} \pm 0.77$ & $90.5^{\mathrm{b}} \pm 0.7$ \\
\hline $12 \mathrm{mo}$ & $106.0^{\mathrm{a}} \pm 0.89$ & $108.4^{\mathrm{b}} \pm 0.76$ & $111.1^{\mathrm{c}} \pm 0.7 \mathrm{C}$ \\
\hline $18 \mathrm{mo}$ & $114.8^{\mathrm{a}} \pm 0.85$ & $117.6^{b} \pm 0.74$ & $119.7^{\mathrm{c}} \pm 0.67$ \\
\hline $24 \mathrm{mo}$ & $128.7^{\mathrm{a}} \pm 0.99$ & $129.7^{\mathrm{a}} \pm 0.83$ & $134.1^{\mathrm{b}} \pm 0.77$ \\
\hline $36 \mathrm{mo}$ & $130.8^{\mathrm{a}} \pm 1.08$ & $132.8^{\mathrm{a}} \pm 0.90$ & $136.8^{\mathrm{b}} \pm 0.86$ \\
\hline \multicolumn{4}{|c|}{ Heart girth, $\mathrm{cm}$} \\
\hline $6 \mathrm{mo}^{\circ}$ & $120.0^{\mathrm{a}} \pm 0.85$ & $121.6^{\mathrm{a}} \pm 0.76$ & $124.3^{\mathrm{b}} \pm 0.69$ \\
\hline $12 \mathrm{mo}$ & $152.1^{\mathrm{a}} \pm 1.12$ & $152.2^{\mathrm{a}} \pm 0.92$ & $155.4^{\mathrm{b}} \pm 0.86$ \\
\hline $18 \mathrm{mo}$ & $167.8^{\mathrm{a}} \pm 0.90$ & $170.7^{\mathrm{b}} \pm 0.80$ & $171.9^{\mathrm{b}} \pm 0.72$ \\
\hline $24 \mathrm{mo}$ & $185.2^{\mathrm{a}} \pm 1.00$ & $186.1^{\mathrm{a}} \pm 0.86$ & $189.2^{\mathrm{b}} \pm 0.79$ \\
\hline $36 \mathrm{mo}$ & $186.0^{\mathrm{a}} \pm 1.13$ & $187.5^{\mathrm{a}} \pm 0.95$ & $191.8^{\mathrm{b}} \pm 0.90$ \\
\hline \multicolumn{4}{|c|}{ Wither height, $\mathrm{cm}$} \\
\hline Birth & $72.7^{\mathrm{a}} \pm 0.67$ & $73.6^{\mathrm{ab}} \pm 0.66$ & $74.9^{\mathrm{b}} \pm 0.57$ \\
\hline $6 \mathrm{mo}$ & $97.0^{\mathrm{a}} \pm 0.72$ & $98.7^{\mathrm{a}} \pm 0.69$ & $100.8^{\mathrm{b}} \pm 0.60$ \\
\hline $12 \mathrm{mo}$ & $117.4^{\mathrm{a}} \pm 0.88$ & $117.1^{\mathrm{a}} \pm 0.78$ & $120.9^{\mathrm{b}} \pm 0.69$ \\
\hline $18 \mathrm{mo}$ & $125.2^{\mathrm{a}} \pm 0.61$ & $127.2^{\mathrm{b}} \pm 0.64$ & $130.7^{\mathrm{c}} \pm 0.52$ \\
\hline $24 \mathrm{mo}$ & $129.4^{\mathrm{a}} \pm 0.70$ & $132.2^{\mathrm{b}} \pm 0.69$ & $135.9^{c} \pm 0.58$ \\
\hline $36 \mathrm{mo}$ & $129.1^{\mathrm{a}} \pm 0.77$ & $131.3^{\mathrm{b}} \pm 0.73$ & $136.2^{\mathrm{c}} \pm 0.64$ \\
\hline
\end{tabular}

${ }^{\mathrm{a}-\mathrm{c}}$ Values within rows with different superscripts differ $(P<0.05)$.

${ }^{1}$ Treatments: NZ70 = a 1970s high Breeding Worth strain of New Zealand Friesian; NZ90 = A 1990s high Breeding Worth HolsteinFriesian of New Zealand origin; NA90 = a 1990s high Breeding Worth Holstein-Friesian of North American origin. age categories, although the differences were small (i.e., $<3 \mathrm{~cm})$ and not always significant. All animals were still growing in BL after $2 \mathrm{yr}$, because animal length at 36 mo was longer $(P<0.001)$ across strains than was animal length at 24 mo.

The trend in HG differences among strains was similar to that observed for BL (Table 3). The NA90 strain had a greater HG $(P<0.05)$ than either of the $2 \mathrm{NZ}$ strains across all ages, with the exception of $18 \mathrm{mo}$. The difference in HG between the NA90 and NZ strains varied from 1 to $6 \mathrm{~cm}$. The difference in HG between the NZ strains was small (i.e., $<4 \mathrm{~cm}$ ) and was not significantly different at 18 mo of age.

With the exception of WH at birth, the NA90 animals were always taller than their NZ counterparts by 1 to $7 \mathrm{~cm}(P<0.05$; Table 3$)$. The NZ90 strain was taller $(P$ $<0.001)$ than the NZ70 strain by up to $2 \mathrm{~cm}$ from 18 mo onward. There was no significant difference in animal WH between NZ90 and NZ70 at 24 and 36 mo, suggesting that animals had reached their mature $\mathrm{WH}$ at 24 mo of age.

The NZ70 strain reached puberty (Table 4 and Figure $1)$ at a lower BW and younger age $(P<0.05)$ than the NZ90 and NA90. The cumulative pregnancy rate is shown in Figure 2. A smaller proportion $(P<0.001)$ of NZ90 strain heifers were pregnant between wk 3 to 6 compared with the other strains; however, by wk 11 there was no significant difference between the strains.

\section{DISCUSSION}

This study is unique in that it compares 2 strains of 1990s genetics (NZ and NA) and 1 strain typical of $\mathrm{HF}$ being farmed in NZ in the 1970s. It is also part of a major HF strain comparison involving Ireland, which allows the investigation of strain by environment interactions. The study has highlighted differences among the 3 strains and the implications for the dairy industry of changing genetics within the NZ HF herd.

The last $25 \mathrm{yr}$ of genetic improvement in NZ have generated a $\mathrm{HF}$ cow that is taller, longer, and $25 \mathrm{~kg}$ heavier at puberty. Compared with modern NZ HF, the NA HF genetics are $20 \mathrm{~kg}$ heavier at puberty. Puberty was attained at 230,253 , and $274 \mathrm{~kg}$ of $\mathrm{BW}$, and at 329,356 , and $373 \mathrm{~d}$ of age in the NZ70, NZ90, and NA90 strains, respectively. These data suggest that the NZ90 and the NA90 strains have heavier mature weights than the NZ70 strain. They also suggest that either these 2 strains are also later maturing than the NZ70 strain or that their ability to grow (especially the NA90 strain) were restricted by their feeding on grazed pastures, with consequent delays in their puberty. In pastoral systems reliant on a 365-d calving interval, this implies that heifers must be grown well enough to reach 
Table 4. Proportion and percentage of animals $(n=190)$, by strain, that a) reached puberty (as measured by blood progesterone levels) before the planned start of mating and b) had reached puberty and were at least $400 \mathrm{~d}$ of age at the end of the sampling period with the mean value for date of birth, age (d), and BW (kg) at puberty; and data for a second group of animals ${ }^{1}$

\begin{tabular}{lccc}
\hline & \multicolumn{3}{c}{ Treatment $^{2}$} \\
\cline { 2 - 4 } Item & NZ70 & NZ90 & NA90 \\
\hline Heifers that attained puberty by planned start of mating, n (\%) & $36 / 41(88)$ & $70 / 73(96)$ & $56 / 76(74)$ \\
Heifers that attained puberty by 400 d, $\%$ & $89^{\text {ab }}$ & $97^{\mathrm{a}}$ & $79^{\mathrm{b}}$ \\
Mean birth date & August 13 & August 7 & August 10 \\
Mean \pm SEM age at puberty, ${ }^{3} \mathrm{~d}$ & $329^{\mathrm{a}} \pm 6.7$ & $356^{\mathrm{b}} \pm 6.9$ & $373^{\mathrm{b}} \pm 6.0$ \\
Mean \pm SEM BW at puberty, $\mathrm{kg}$ & $230^{\mathrm{a}} \pm 4.9$ & $253^{\mathrm{b}} \pm 4.9$ & $274^{\mathrm{c}} \pm 4.4$ \\
Mean \pm SEM age at puberty, ${ }^{1} \mathrm{~d}$ & $381 \pm 8.1$ & $380 \pm 6.5$ & $374 \pm 6.5$ \\
Mean \pm SEM body weight at puberty, ${ }^{1} \mathrm{~kg}$ & $237^{\mathrm{a}} \pm 7.3$ & $258^{\mathrm{b}} \pm 5.9$ & $271^{\mathrm{b}} \pm 6.0$ \\
\hline
\end{tabular}

${ }^{\mathrm{a}-\mathrm{c}}$ Values within rows with different superscripts differ $(P<0.05)$.

${ }^{1}$ Adapted from McNaughton et al. (2002). Year 2 of the strain trial $(\mathrm{n}=81)$.

${ }^{2}$ Treatments: NZ70 = a 1970s high Breeding Worth strain of New Zealand Friesian; NZ90 = a 1990s high Breeding Worth Holstein-Friesian of New Zealand origin; NA90 = A 1990s high Breeding Worth HolsteinFriesian of North American origin.

${ }^{3}$ Difference between NZ90 and NA90 approached significance $(P=0.07)$.

puberty and calve by $24 \mathrm{mo}$. In the experiment reported here, $26 \%$ of the NA heifers had not attained puberty by the planned start of mating, which means that for farmers with these animals, there will be difficulties in ensuring they calve at close to 24 mo of age.

Because NZ has a pasture-based seasonal calving system, there is a demand for heifers to become pregnant in the short period of 6 to $8 \mathrm{wk}$. Failure to do so means that first-calving heifers may have difficulty surviving to the next season as a result of a longer anestrus period, and consequently have less time to get back in calf. In the current trial, the NZ90 heifers had a lowered cumulative pregnancy rate, which was due to a lameness problem with the bulls that were in their group and fresh bulls not being brought in to replace them. Sixty percent of the NZ90 heifers were pregnant at 3 wk, which was slightly lower than for the NZ70 and NA90 heifers, and this difference between strains continued to $7 \mathrm{wk}$. Regardless, this had no effect on the total number of heifers pregnant after 11 wk of mating (100, 97, and $95 \%$ for the NZ70, NZ90 and NA90 strains, respectively). However, this did result in a difference

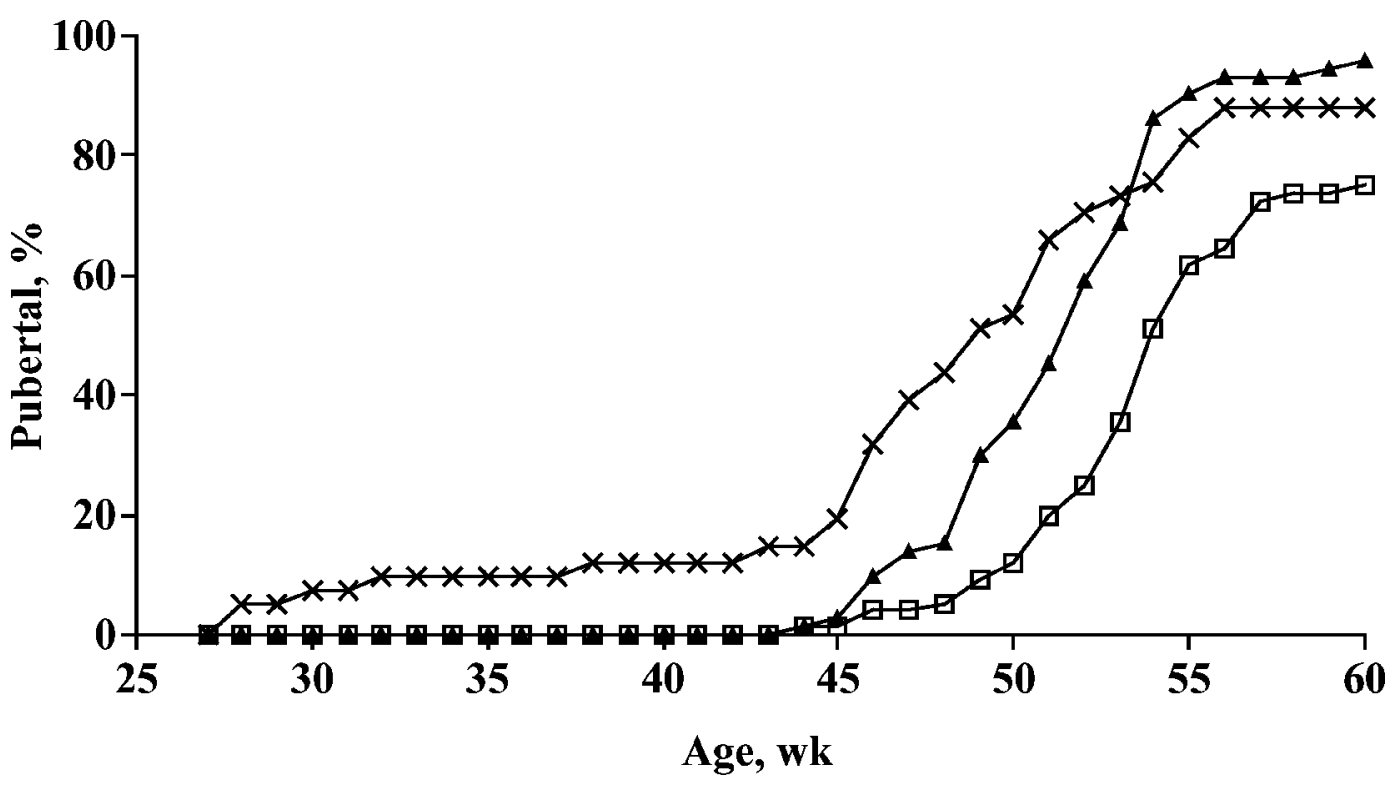

Figure 1. Cumulative pubertal rate (\%) for 3 strains of Holstein-Friesian. Treatments: NZ70 $(\times)=$ a 1970s high Breeding Worth strain of New Zealand Friesian; NZ90 $(\mathbf{\Delta})=$ a 1990 high Breeding Worth Holstein-Friesian of New Zealand origin; NA90 $(\square)=$ a 1990 high Breeding Worth Holstein-Friesian of North American origin. 


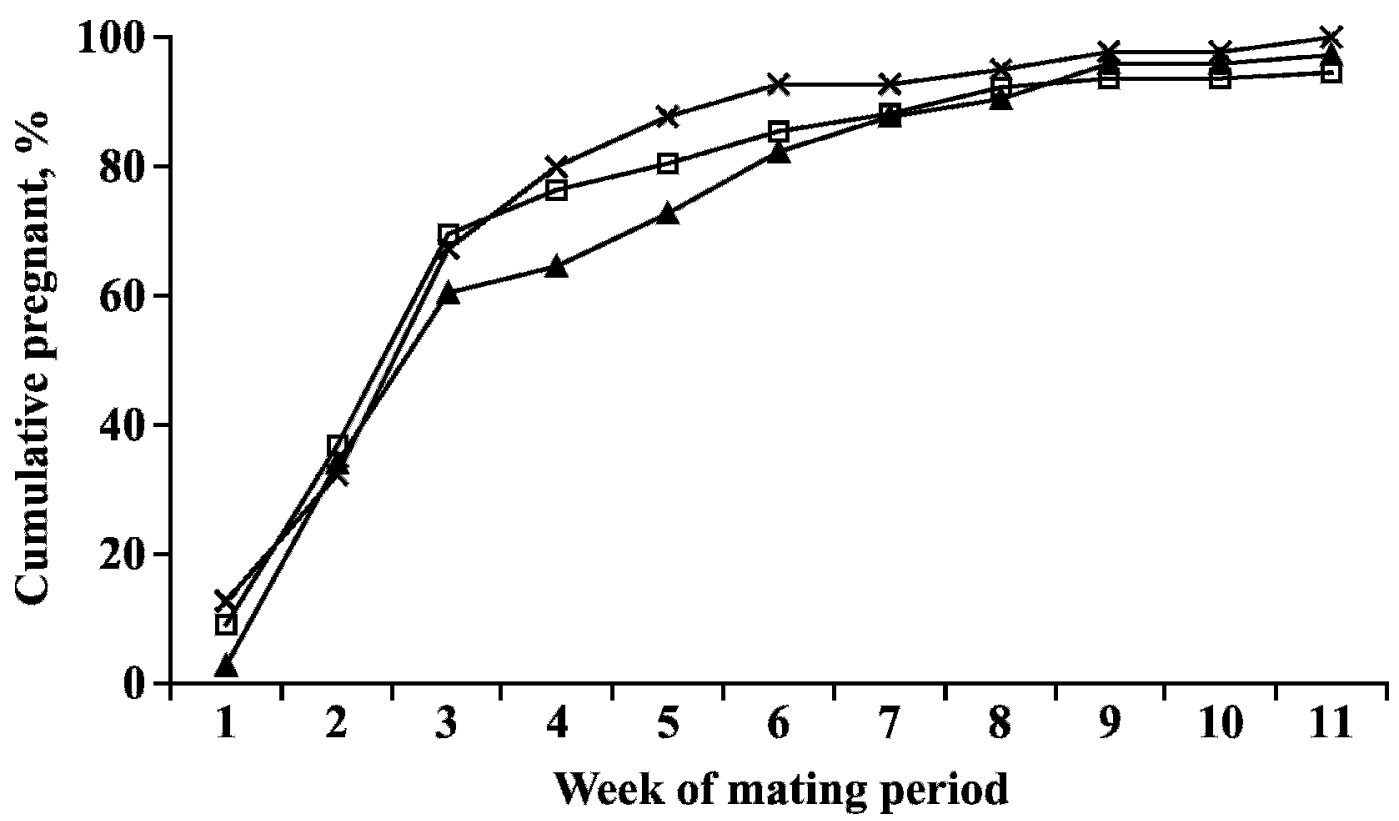

Figure 2. Cumulative pregnancy rate $(\%)$ for 3 strains of Holstein-Friesian. Treatments: NZ70 $(\times)=$ a 1970s high Breeding Worth strain of New Zealand Friesian; NZ90 $(\boldsymbol{\Delta})=$ a 1990s high Breeding Worth Holstein-Friesian of New Zealand origin; NA90 $(\square)=$ a 1990 s high Breeding Worth Holstein-Friesian of North American origin.

in mean calving date in the following season (August 7, August 12, and August 8 for the NZ70, NZ90, and NA90 strain, respectively).

The measurements made in this study are broadly consistent with previous reports. Body weights at puberty for the NZ90 cows in the current study were similar to that reported by McGrath et al. (2001) and in another NZ study (Macdonald et al., 2005b), although they were higher than those reported by Penno (1994; $220 \mathrm{~kg}$ ) and García-Muñiz (1998; $221 \mathrm{~kg}$ ) for the light animals of mature BW (Table 5). In an Irish companion study, McGrath et al. (2001) reported that heifers of NA ancestry reached puberty at $298 \mathrm{~kg}$ and $369 \mathrm{~d}$ of age (Table 5), which is $24 \mathrm{~kg}$ heavier but of a similar age to the NA90 strain in the current study, whereas the NZ90 animals in Ireland were $12 \mathrm{~kg}$ lighter and $56 \mathrm{~d}$ younger when puberty was reached.

In this study there were differences in BW and age when the heifers reached puberty. McNaughton et al. (2002) reported that in a group of yearlings $(n=81)$ that were reared the year after the present trial, there was no difference in age at puberty, although there were differences between strain and BW at puberty. In that group of animals, the planned growth rates were not attained and the animals were approximately 20 $\mathrm{kg}$ lighter than the target at the end of May (10 mo of age). This supports other studies (Hafez and Hafez, 2000; Macdonald et al., 2005b) that have shown that attainment of puberty depends more on BW than on age. These results indicate that the genetic strain of $\mathrm{HF}$ influences age at puberty, mainly through the influence of strain on BW. Twenty-one percent of the NA90 heifers, compared with only $3 \%$ of the NZ90 heifers, were close to, but had not reached, puberty at the planned start of mating. This has implications for seasonal calving systems if the target BW is not achieved, because heifers may not become pregnant, and this may be more likely for NA- than NZ-type heifers. Byerley

Table 5. Comparative age and BW at puberty for strain trial animals in New Zealand (this trial) and Ireland, an effect of feeding trial, and a comparison between 2 strains of Holstein-Friesian that had a low and high mature $\mathrm{BW}$

\begin{tabular}{|c|c|c|c|c|}
\hline \multirow[b]{3}{*}{ Item } & \multicolumn{4}{|c|}{ Treatment $^{1}$} \\
\hline & \multicolumn{2}{|c|}{ Age, $d$} & \multicolumn{2}{|c|}{$\mathrm{BW}, \mathrm{kg}$} \\
\hline & NZ90 & NA90 & NZ90 & NA90 \\
\hline This trial data, yr $1^{2}$ & 356 & 373 & 253 & 274 \\
\hline Irish trial $^{3}$ & 300 & 369 & 241 & 298 \\
\hline Effect of feeding trial ${ }^{4}$ & $355-419$ & & 251 & \\
\hline Differing mature BW trial 5 & Low & High & Low & High \\
\hline $\mathrm{BW}^{5}$ & 300 & 325 & 221 & 241 \\
\hline
\end{tabular}

${ }^{1}$ NZ90 = a 1990 high Breeding Worth Holstein-Friesian of New Zealand origin; NA90 = a 1990 high Breeding Worth HolsteinFriesian of North American origin.

${ }^{2}$ Adapted from McNaughton et al. (2002).

${ }^{3}$ Adapted from McGrath et al. (2001).

${ }^{4}$ Adapted from Macdonald et al. (2005b).

${ }^{5}$ Adapted from García-Muñiz (1998). 
et al. (1987) found that beef heifers bred to their first estrus had significantly lower conception rates than those bred to the third estrus following puberty. To maximize the conception rate, it is essential for a heifer to have already reached puberty before the start of the mating period. Selection over the last $25 \mathrm{yr}$ appears to have resulted in heifers needing to reach a higher BW before they attain puberty (NZ90 vs. NZ70). This could indicate that the NZ90 heifers have a higher mature BW than the EBV suggest, or that they are later maturing.

Birth weights of the NA90 were similar to those reported by Berry et al. (2005) across $2 \mathrm{HF}$ strains of NA ancestry in the Irish companion study, which was on a pasture-based system of milk production. The NZ70 birth weights were similar to the NZ HF selected for low BW (García-Muñiz, 1998). Birth weights of the NZ90 strain, however, were higher than the $36 \mathrm{~kg}$ reported for Ireland by Berry et al. (2005) and also the $37 \mathrm{~kg}$ reported by Macdonald et al. (2005b) for NZ HF, but were similar to the average birth weights of $\mathrm{HF}$ selected for high BW with about 30\% US genetics (GarcíaMuñiz, 1998).

The 6- and 15-mo BW of 162 and $337 \mathrm{~kg}$ for the NZ90 strain are similar to those reported by Macdonald et al. (2005b) for NZ HF reared to achieve a medium growth rate. The NA90 strain did not achieve the recommended target BW of $537 \mathrm{~kg}$ at 24 mo (Bryant et al., $2004)$, but were close to that $(519 \mathrm{~kg}$ ) reported by Kolver et al. (2000). The NZ90 strain was close to the $500 \mathrm{~kg}$ recommended by Bryant et al. (2004) but were approximately $40 \mathrm{~kg}$ heavier than the BW reported by Kolver et al. (2000).

Recommendations on the optimum BW at first calving vary widely, with those for high-concentrate, intensive feeding systems targeting 540 to $650 \mathrm{~kg}$ of BW before first calving (Heinrichs, 1993), whereas a more modest first-calving BW is accepted in pasture-based systems (490 to $550 \mathrm{~kg}$; McLean and Freeman, 1996; Holmes et al., 2002). Further, Lean (1994) suggested that the optimum BW at first calving will differ according to the milk production system; thus, the HF cows in a pasture-based system will be smaller than those fed TMR. In this study, the $2 \mathrm{NZ}$ strains were at the lower end of the pasture-based recommendations and the NA were slightly higher. In NZ it is recommended that optimum yearling fertility and cow production be achieved when heifers reach 60 and $90 \%$ of their mature BW at $15 \mathrm{mo}$ (mating) and $24 \mathrm{mo}$ (calving), respectively (Penno et al., 1995). In this experiment, the BW of the strains were 29,31 , and $30 \%$ at 6 mo; 63,65 , and $65 \%$ at $15 \mathrm{mo}$; and 93,95 , and $93 \%$ at 24 mo of their estimated mature BW for the NZ70, NZ90, and NA90 strains, respectively. The estimated mature
BW (calculated from the EBV) for the NZ strains were similar $(519 \mathrm{~kg})$, with the NA predicted to be higher $(555 \mathrm{~kg})$. The fact that there was a BW difference between the NZ strains, when the EBV for BW were similar, suggests that the BW EBV for one of the strains is incorrect and that possibly the NZ70 could be too high because of a lack of information. When adjusted for BCS at $24 \mathrm{mo}$, the BW difference of $35 \mathrm{~kg}$ between the NA90 and NZ90 strains is close to what would be expected from their BW EBV (47, 49, and 83 for the NZ70, NZ90, and NA90 strains, respectively).

The NA90 first-calving heifers did not reach the target BCS of 5.5 to 6.0 (3.25 to 3.40 on a US 5-point scale) at calving. The significant difference in BW at first calving following adjustment for differences in BCS demonstrates that there are large effects of BCS on the actual BW of the cows. Similarly, Berry et al. (2003) reported no genetic correlation between milk production and BW; however, following adjustment for differences in BCS, the correlation between milk production and $\mathrm{BW}$ was positive, indicating that genetic selection for greater milk production increased body size but reduced BCS, thereby having a negligible effect on overall BW.

Although not significant, average mature BL of the NA strains in the Irish study were numerically greater than the average mature BL of the NZ strain (Berry et al., 2005). The differences in actual BL reported in the present study and by Berry et al. (2005) may be due to the different measures used. Berry et al. (2005) also reported larger HG in the 2 NA strains compared with a NZ strain, although the difference between the NA $\mathrm{HF}$ and NZ HF strains was not significant in that study. The difference in HG between the strains is unlikely to be due to differences in genetic merit for milk production, because negligible genetic correlations have been reported between HG and fat and protein yield in Italian HF (Gallo et al., 2001).

Although HG differences between the $2 \mathrm{NZ}$ strains in the present study were generally not significantly different from each other, there was a tendency for larger HG over time in the NZ animals. The 6-mo HG measurement for all strains was at least $6 \mathrm{~cm}$ greater than that reported by Macdonald et al. (2005b). The mature HG dimensions reported by Berry et al. (2005) were larger than those reported in the present study for animals at 36 mo of age. Additionally, the mean HG reported by Gallo et al. (2001) in pluriparous Italian $\mathrm{HF}(201 \mathrm{~cm})$ was larger than that reported in the present study.

At 15 and 24 mo, the NZ90 strain was 117 and 128 $\mathrm{cm}$ tall $(\mathrm{WH})$ which is similar to the WH reported by Macdonald et al. (2005b) for similarly aged heifers that were typical of the NZ HF heifers in the early 1990s. 
The NA90 heifers were taller than the NZ90 heifers, and they in turn were taller than the NZ70 heifers at all stages older than 18 mo. The NA90 cows were 136 $\mathrm{cm}$ tall at $24 \mathrm{mo}$, which is close to the $138 \mathrm{~cm}$ reported by Kertz et al. (1997) for a NA study but taller than that reported by Heinrichs and Hargrove (1987). Both NA strains were significantly taller (by 6 to $7 \mathrm{~cm}$ ) than the NZ strain at maturity in the Irish study (Berry et al., 2005). Hence, selection in NZ from 1970 to 1990 has favored taller animals. This is partly attributed to the positive genetic correlation between stature and milk production (Berry et al., 2004) and the active genetic selection for increased milk production in NZ during that time. This is also one reason why the NA90 strain was taller than the NZ90, the difference being further compounded by conscious selection toward a smaller body size in NZ. There was more spread in WH between the NA90 and NZ70 strains, with the NZ90 strain being closer to the NZ70 strain. This result indicates more "frame" on the NA90 heifers but that BW has not kept up with WH. This suggests a tendency for genetic selection from 1970 to 1990 in NZ to increase $\mathrm{BL}, \mathrm{WH}, \mathrm{HG}$, and $\mathrm{BW}$ of the HF population.

\section{CONCLUSIONS}

This study highlights differences in growth parameters and puberty among strains of different genetic origin. The NA animals were taller, were longer, and had larger $\mathrm{HG}$ at older ages than did their NZ contemporaries. The NZ70 heifers were lighter than the NZ90 heifers early in life but were similar at 15 and $24 \mathrm{mo}$, whereas the differences between the NZ90 and NA90 heifers increased with age. The differences were smaller than expected, but this was partly attributed to the lower BCS of the NZ90 strain relative to the NZ70 strain and the lower BCS of the NA strain relative to the NZ strains, as well as to BW measurements not being reported past 24 mo of age. To attain puberty, the NA heifers must be approximately $20 \mathrm{~d}$ older and $20 \mathrm{~kg}$ heavier than the NZ90 heifers, and in turn, the NZ90 heifers need to be $25 \mathrm{~kg}$ heavier and $25 \mathrm{~d}$ older than their 1970s counterparts. The NA90 heifers have a heavier mature BW, and their older age at puberty suggests either that they mature later or that, under pastoral conditions, their growth rate is limited by their inability to consume sufficient metabolizable energy as grazed pasture, with a consequent delay in puberty. This has important implications for the HF in NZ, because they now have $48 \%$ of their genetics from NA, and has implications as well for all other countries rearing heifers in pasture-based systems.

\section{ACKNOWLEDGMENTS}

This study was funded by New Zealand dairy farmers through the Dairy InSight research fund (contract number 10082) and Livestock Improvement Corporation (now LIC). The study is part of a joint project between Dexcel, LIC, Massey University (New Zealand), and Teagasc (Moorepark, Ireland). We would like to acknowledge the support of Pat Dillon and other Teagasc staff. The authors gratefully acknowledge the contribution of Chris Glassey, Bruce Thorrold (Dexcel), Rob Jackson, Jack Hooper, and David Sellars (LIC) who were all on the Dexcel Strain Trial Committee. The assistance of the Dexcel staff at the Grazing Unit, and Rob Thompson in particular, is especially recognized.

\section{REFERENCES}

Berry, D. P., F. Buckley, P. Dillon, R. D. Evans, M. Rath, and R. F. Veerkamp. 2003. Genetic relationships among body condition score, body weight, milk yield and fertility in dairy cows. J. Dairy Sci. 86:2193-2204.

Berry, D. P., F. Buckley, P. Dillon, R. D. Evans, and R. F. Veerkamp. 2004. Genetic relationships among linear type traits, milk yield, body weight, fertility and somatic cell count in primiparous dairy cows. Irish J. Agric. Food Res. 43:161-176.

Berry, D. P., B. Horan, and P. Dillon. 2005. Comparison of growth curves of three strains of female dairy cattle. Anim. Sci. 80:151-160.

Bryant, J. R., C. W. Holmes, N. Lopez-Villalobos, L. R. McNaughton, I. M. Brookes, and J. E. Pryce. 2004. Use of breeding values for live weight to calculate individual live weight targets for dairy heifers. Proc. N. Z. Soc. Anim. Prod. 64:118-121.

Byerley, D. J., R. B. Staigmiller, J. G. Berardinelli, and R. E. Short. 1987. Pregnancy rates of beef heifers bred either on puberal or third oestrus. J. Anim. Sci. 65:645-650.

Foster, D. L. 1994. Puberty in the sheep. Pages 411-451 in The Physiology of Reproduction. E. Knobil and J. D. Neil, ed. Raven Press Ltd., New York, NY.

Gallo, L., P. Carnier, M. Cassandro, R. Dal Zotto, and G. Bittante. 2001. Test-day genetic analysis of conditions core and heart girth in Holstein-Friesian cows. J. Dairy Sci. 84:2321-2326.

García-Muñiz, J. G. 1998. Studies of Holstein-Friesian Cattle Bred for Heavy or Light Mature Live Weight. PhD Thesis. Massey University, Palmerston North, New Zealand.

Hafez, E. S. E., and B. Hafez. 2000. Reproductive Cycles. Pages 5567 in Reproduction in Farm Animals. B. Hafez and E. S. E. Hafez, ed. Lippincott Williams \& Wilkins, Philadelphia, PA.

Harris, B. L., and E. S. Kolver. 2001. Review of Holsteinization on intensive pastoral dairy farming in New Zealand. J. Dairy Sci. 84(E. Suppl.):E56-E61.

Heinrichs, A. J. 1993. Raising dairy replacements to meet the needs of the 21st century. J. Dairy Sci. 76:3179-3187.

Heinrichs, A. J., and G. L. Hargrove. 1987. Standards of weight and height for Holstein Heifers. J. Dairy Sci. 70:653-660.

Holmes, C. W. 1995. Genotype $\times$ environment interaction in dairy cattle: A New Zealand perspective. Pages 51-66 in Breeding and Feeding the High Genetic Merit Dairy Cow. Occ. Pub. No. 19. British Society of Animal Science, Penicuik, Midlothian, Scotland.

Holmes, C. W., I. M. Brookes, D. J. Garrick, D. D. S. Mackenzie, T. J. Parkinson, and G. F. Wilson. 2002. Feeding and management of heifer replacements. Pages 119-128 in Milk Production from Pasture. Massey University Press, Palmerston North, New Zealand.

Horan, B., J. F. Mee, P. O'Connor, M. Rath, and P. Dillon. 2004. The effect of strain of Holstein-Friesian cow and feed system 
on reproductive performance in seasonal-calving milk production systems. Anim. Sci. 79:453-468.

Kertz, A. F., L. F. Reutzel, and B. A. Barton. 1997. Body weight, body condition score, and wither height of prepartum Holstein cows and birth weight and sex of calves by parity: A database and summary. J. Dairy Sci. 80:525-529.

Kolver, E. S., A. R. Napper, P. J. A. Copeman, and L. D. Muller. 2000. A comparison of New Zealand and overseas Holstein Friesian heifers. Proc. N. Z. Soc. Anim. Prod. 60:264-269.

Lean, I. 1994. Calf to cow-Care and Profit. Tech. Bull. Smith Kline Beecham Animal Health, Sydney, Australia.

Macdonald, K. A., and J. W. Penno. 1998. Management decision rules to optimise production on dairy farms. Proc. N. Z. Soc. Anim. Prod. 58:132-135.

Macdonald, K. A., J. W. Penno, A. M. Bryant, and J. R. Roche. 2005b. Effect of feeding level pre- and post-puberty and body weight at first calving on growth, milk production, and fertility in grazing dairy cows. J. Dairy Sci. 88:3363-3375.

Macdonald, K., and J. Roche. 2004. Condition Scoring Made Easy: Condition scoring dairy herds. 1st ed. Dexcel Ltd., Hamilton, New Zealand.

Macdonald, K. A., B. S. Thorrold, C. B. Glassey, C. W. Holmes, and J. E. Pryce. 2005a. Impact of farm management decision rules on the production and profit of different strains of Holstein-Friesian dairy cows. Proc. N. Z. Soc. Anim. Prod. 65:40-45.

McGrath, M. E., J. F. Mee, S. E. M. Snijders, and D. Ocallaghan. 2001. The effect of genotype on the onset of puberty and subse- quent fertility in dairy heifers. Page 46 in Proc. Agric. Res. Forum, Tullamore, Ireland. M. G. Diskin, ed. Standard Printers, Galway, Ireland.

McNaughton, L. R., S. R. Morgan, P. Gore, G. A. Verkerk, and C. W. Holmes. 2002. Monitoring onset of puberty in three strains of Holstein-Friesian dairy cattle. Proc. N. Z. Soc. Anim. Prod. 62:30-33.

McLean, D. M., and M. Freeman. 1996. Benefits from better grown heifers. Proc. Aust. Soc. Anim. Prod. 21:72-75.

Penno, J. 1994. Growing replacements. Proc. Ruakura Farmers' Conf. 46:36-42.

Penno, J. W., K. L. Macmillan, and A. M. Bryant. 1995. Effect of level of nutrition on age of puberty and reproductive performance of Friesian heifers. Proc. N. Z. Soc. Anim. Prod. 55:79-81.

Roche, J. R., D. P. Berry, and E. S. Kolver. 2006. Holstein-Friesian Strain and feed effects on milk production, body weight, and body condition score profiles in grazing dairy cows. J. Dairy Sci. 89:3532-3543.

SAS Institute. 2005. SAS User's Guide. Version 8.0.0 Edition. SAS Inst., Inc., Cary, NC.

Sejrsen, K., and S. Purup. 1997. Influence of prepubertal feeding level on milk yield potential of dairy heifers: A review. J. Anim. Sci. 75:828-835.

Spelman, R. J., and D. J. Garrick. 1997. Effect of live weight and differing economic values on responses to selection for milk fat, protein, volume, and live weight. J. Dairy Sci. 80:2557-2562. 